\title{
Sanguinarine Increases Sensitivity of Human Gastric Adenocarcinoma Cells to TRAIL-mediated Apoptosis by Inducing DR5 Expression and ROS Generation
}

\author{
Taek Ju Lee ${ }^{1}$, Im Yong Gyun ${ }^{1}$, Woo Young $\mathrm{Choi}^{2}$, Sung Hyun $\mathrm{Choi}^{3}$, Won Deok Hwang ${ }^{1 *}$ and \\ Yung Hyun $\mathrm{Choi}^{4 *}$ \\ ${ }^{1}$ Department of Internal Medicine, Dongeui University College of Korean Medicine, Busan 614-052, Korea \\ ${ }^{2}$ Division of Meridian and Structural Medicine, School of Korean Medicine, Busan National University, Gyeongnam 626-870, Korea \\ ${ }^{3}$ Department of System Management, Korea Lift College, Geochang 670-802, Korea \\ ${ }^{4}$ Department of Biochemistry, Dongeui University College of Oriental Medicine, Busan 614-052, and Anti-Aging Research Center \& Blue-Bio \\ Industry RIC, Dongeui University, Busan 614-714, Korea
}

Received June 16, 2014 /Revised September 23, 2014 /Accepted September 24, 2014

\begin{abstract}
Sanguinarine, a benzophenanthridine alkaloid originally derived from the root of Sanguinaria canadensis, has been shown to possess antimicrobial, antioxidant, and anti-cancer properties. Although tumor necrosis factor-related apoptosis-inducing ligand (TRAIL) is known to induce apoptosis in cancer cells, but not most normal cells and has shown efficacy in a phase 2 clinical trial, development of resistance to TRAIL by tumor cells is a major roadblock. Our previous study indicated that treatment with TRAIL in combination with subtoxic concentrations of sanguinarine sensitized TRAIL-mediated apoptosis in TRAIL-resistant human gastric carcinoma AGS cells; however, the detailed mechanisms are not fully understood. In this study, we show that sanguinarine sensitizes AGS cells to TRAILmediated apoptosis as detected by MTT assay, agarose gel electrophoresis, chromatin condensation and flow cytometry analysis. Combined treatment with sanguinarine and TRAIL effectively induced expression of death receptor (DR) 5 but did not affect expression of DR4 and mitogen activated protein kinases signaling molecules. Moreover, the combined treatment with sanguinarine and TRAIL increased the generation of reactive oxygen species (ROS); however, $\mathrm{N}$-acetylcysteine, ROS scavenger, significantly recovered growth inhibition induced by the combined treatment. Taken together, our results indicate that sanguinarine can potentiate TRAIL-mediated apoptosis through up-regulation of DR5 expression and ROS generation.
\end{abstract}

Key words : Apoptosis, death receptor 5, reactive oxygen species, sanguinarine, TRAIL (tumor necrosis factor-related apoptosis-inducing ligand)

\section{서 론}

세포막 관통 단백질(transmembrane protein)의 일종인 tumor necrosis factor-related apoptosis-inducing ligand (TRAIL)는 apoptosis의 주요 경로 중의 하나인 extrinsic pathway 활성 매개 인자 중의 하나이다. TRAIL은 세포막에 결합 된 death receptor (DR)와 결합함으로써 세포 내 death domain들을 통한 apoptosis 신호를 전달한다 $[15,30]$. TRAIL의 apoptosis 유도 작용은 TRAIL receptor와 caspase-8 활성 의존

\section{${ }^{*}$ Corresponding author}

Tel : +82-51-850-8625, Fax : +82-51-853-4036

E-mail : wdhwang@deu.ac.kr (Won Deok Hwang)

Tel : +82-51-850-7413, Fax : +82-51-853-4036

E-mail : choiyh@deu.ac.kr (Yung Hyun Choi)

This is an Open-Access article distributed under the terms of the Creative Commons Attribution Non-Commercial License (http://creativecommons.org/licenses/by-nc/3.0) which permits unrestricted non-commercial use, distribution, and reproduction in any medium, provided the original work is properly cited
적으로 일어나며, TRAIL에 의하여 활성화된 caspase-8은 caspase-3 및 -7을 포함하는 effector caspase를 활성화시키는 caspase cascade의 작용을 촉진한다 $[15,25]$. 그러나 이러한 현상 은 암세포 특이적으로 나타나며, TRAIL이 apoptosis 유도를 통한 항암효능 증대에 대한 phase 2 clinical trial에 적용되고 있지만, 많은 암세포들이 이미 TRAIL에 대한 저항성을 획득 하고 있다는 점에서 TRAIL의 감수성을 탁월하게 높일 수 있 는 물질의 발굴이 시급한 실정이다[4, 31].

Sanguinarine (13-methylbenzodi-oxolo[5,6-]-1,3-dioxolo[4, 5-I] phenanthridinium)은 전통 한의학에서 오랜 동안 사용되 어 온 혈근초(Sanguinaria canadensis) 및 현호색과(Fumaria species) 식물의 뿌리에 존재하는 benzophenanthridine alkaloid계열 물질의 일종으로 구조적으로 chelerythrine와 유사하 다[2, 3, 27]. Sanguinarine은 항균, 항염증, 항산화, 항암활성을 포함한 다양한 약리적 효능을 지니고 있는 것으로 알려져 있 다 $[16,20,23,24,26]$. 최근 본 연구실의 결과에 의하면, sanguinarine은 교아종(glioblastoma) 세포에서 mitogen activated 
protein kinases (MAPKs) 신호 전달 분자 중의 하나인 extracellular signal-regulated kinase (ERK)와 phosphatidylinositol 3'-kinase (PI3K)/Akt 경로의 차단을 통한 caspase의 활 성과 Bcl-2 family 인자들의 발현 변화를 동반하면서 apoptosis를 유발하였으며[11], 인체 혈구암세포에서도 이와 유사한 경향성을 보여주었다[12]. 또한 sanguinarine에 의한 인체 유 방암세포의 apoptosis 유발은 reactive oxygen species (ROS) 생성 의존적 미토콘드리아 활성화를 통하여 일어났음을 알 수 있었고[7], 인체 유방암세포의 전이 억제는 치밀 결합(tight junction)의 활성 증가와 matrix metalloproteinase 활성 증가 와 연관성이 있었다[6]. 아울러 인체 방광암과 대장암세포에서 sanguinarine에 의한 apoptosis 유발은 early growth response gene-1 전사활성 증대를 통한 ROS 생성 의존적이었음을 보고 한 바 있다 $[13,14]$. 특히 sanguinarine은 인체 위암세포에서 TRAIL 매개 apoptosis를 촉진할 수 있음 확인한 바 있는데, 이 과정은 PI3K/Akt 경로 억제 및 caspase-3의 활성 증가가 관여하고 있음을 알 수 있었으며 $[5,7,12,16,21]$, 이러한 TRAIL 감수성 증대는 유방암세포에서도 확인된 바 있다[21]. 그러나 sanguinarine의 TARIL 감수성 증대에 대한 자세한 기 전은 여전히 많이 알려진 바 없는 실정이며, 이에 대한 추가적 인 연구가 요구되는 실정이다.

따라서 본 연구에서는 TRAIL 저항성이 확인된 바 있는 인 체 위선암(gastric adenocarcinoma) AGS 세포[19]를 이용하여 sanguinarine의 TRAIL 감수성 증진에 대한 추가적인 연구를 실시하였으며, sanguinarine과 TRAIL의 동시 처리에 의한 apoptosis 유발은 DR5의 발현 증가 및 ROS 생성 의존적임을 보고하고자 한다.

\section{재료 및 방법}

\section{세포배양}

본 연구에 사용된 AGS 위암세포는 American Type Culture Collection (Rockville, MD, USA)에서 구입하였으며 $37^{\circ} \mathrm{C}, 5 \%$ $\mathrm{CO}_{2}$ 조건에서 $10 \%$ heat-inactivated fetal bovine serum (FBS, Gibco-BRL, Gaithersburg, MD, USA)과 1\% penicillin-streptomycin (Gibco-BRL)이 혼합된 RPMI-1640 배지를 사용하여 배양하였다.

\section{Sanguinarine과 TRAIL의 처리 및 MTT assay}

Sanguinarine은 Sigma-Aldrich Chemical Co. (St Louis, $\mathrm{MO}, \mathrm{USA}$ )에서 구입하였으며, methanol을 이용하여 $10 \mathrm{mM}$ 농도의 stock 용액을 만들었으며, 이를 배지에 적절히 희석하 여 처리하였다. TRAIL은 KOMA Biotech Co. (Seoul, Republic of Korea)에서 구입하였으며, 증류수에 희석하여 $100 \mu \mathrm{g} / \mathrm{ml}$ 농도의 stock 용액을 만들어 처리하였다. AGS 세포의 증식에 미치는 sanguinarine과 TRAIL의 영향을 조사하기 위해서는 3-(4,5-dimethyl-2 thiazolyl)-2,5-diphnyl-2H-tetrazolium bromide (MTT, Sigma-Aldrich)가 미토콘드리아 효소에 의하여 MTT-formazan을 형성하는 원리에 기반을 둔 MTT assay를 이용하여 조사하였다[6].

\section{Agarose gel 전기영동에 의한 DNA fragmentation}

Apoptosis 유발의 대표적인 증거인 DNA 단편화 현상의 분석을 위하여 준비된 세포에 lysis buffer $[5 \mathrm{mM}$ Tris-HCl (pH 7.5), $5 \mathrm{mM}$ EDTA, 0.5\% TritonX-100]를 첨가하여 상온에 서 1 시간 동안 lysis 시켰다. 회수된 상층액에 proteinase $\mathrm{K}$ solution (Sigma-Aldrich)을 처리한 후 phenol : chloroform : isoamyl alcohol 혼합 용액(25:24 :1, Sigma-Aldrich)을 첨가 하고 적정 시간 반응시켰다. 여기서 얻어진 상층액에 isopropanol (Sigma-Aldrich)과 $5 \mathrm{M}$ 의 $\mathrm{NaCl}$ 를 첨가하여 $4^{\circ} \mathrm{C}$ 에 서 24시간 동안 반응시킨 후, 상층액을 제거하고 DNA pellet 을 추출하였다. 추출된 DNA를 gel loading dye (Bioneer, Daejeon, Republic of Korea)와 섞은 후 $1.0 \%$ agarose gel을 이용하여 분리한 후 ethidium bromide (EtBr, Sigma-Aldrich) 로 염색하여 DNA 단편화 현상을 확인하였다[5].

\section{DAPI 염색에 의한 핵 형태의 변화 관찰}

Apoptosis가 유발되었을 경우 특이적으로 나타나는 핵의 형태적 변화를 관찰하기 위하여 준비된 세포를 $37 \%$ formaldehyde 용액과 PBS를 1:9의 비율로 섞은 fixing solution을 이용하여 고정하였다. 고정된 세포를 cytospin하여 slide glass 에 부착하고 slide glass를 PBS로 2 3회 정도 세척하고 $0.2 \%$ 의 Triton X-100 (Amresco, Solon, OH, USA)을 첨가하여 상온 에서 10 분간 고정한 후 $2.5 \mathrm{mg} / \mathrm{ml}$ 농도의 4',6-diamidino-2phenylindole (DAPI, Sigma-Aldrich) 용액을 처리하여 상온 에서 15 분간 염색하였다. 염색이 끝난 후 DAPI 용액을 충분하

Table 1. Sequences of the primer pairs employed in the RT-PCR reactions

\begin{tabular}{cll}
\hline Gene name & \multicolumn{1}{c}{ Sequence of primers } \\
\hline \multirow{2}{*}{ DR4 } & Sense & 5'-CAG AAC GTC CTG GAG CCT GTA AC-3' \\
& Antisense & $5^{\prime}$-ATG TCC ATT GCC TGA TTC TTT GTG-3' \\
\multirow{2}{*}{ DR5 } & Sense & $5^{\prime}$-GGG AAG AAG ATT CTC CTG AGA TGT G-3' \\
& Antisense & $5^{\prime}$-ACA TTG TCC TCA GCC CCA GGT CG-3' \\
\hline \multirow{2}{*}{ GAPDH } & Sense & $5^{\prime}$-CGG AGT CAA CGG ATT TGG TCG TAT-3' \\
& Antisense & $5^{\prime}$-AGC CTT CTC CAT GGT GGT GAA GAC-3' \\
\hline
\end{tabular}


게 세척하고 mounting solution을 처리한 후 형광 현미경을 이용하여 400 배의 배율로 각 농도에 따른 암세포 핵의 형태 변화를 관찰하였다[13].

\section{Flow cytometry에 의한 apoptosis 정량적 분석}

Sanguinarine과 TRAIL의 단독 또는 복합 처리에 따른 AGS 세포의 apoptosis 유발 정도를 정량적으로 분석하기 위하여 48시간 동안 처리된 세포들을 모은 다음 CycleTEST PLUS DNA REAGENT Kit (Becton Dickinson, San Jose, CA, USA) 를 이용하여 고정 및 염색을 하여 $4^{\circ} \mathrm{C}$, 암실에서 30 분 동안 반응을 시켰다. 반응시킨 세포를 35-mm mesh를 이용하여 단 일세포로 분리한 후 FACSCalibur (Becton Dickinson)를 적용 시켜 형광반응에 따른 cellular DNA content 및 histogram을 CellQuest software 및 ModiFit LT (Becton Dickinson) 프로그 램을 이용하여 분석하여 sub-G1기에 해당되는 세포의 빈도를 측정하였다[14].

RNA의 분리 및 reverse transcription-polymerase chain reaction (PCR)

전사수준에서 DR4 및 DR5의 발현 변화를 조사하기 위하여 적정 조건에서 배양된 세포들의 RNA를 RNeasy kit (Qiagen, La Jolla, CA, USA)를 이용하여 분리한 후, AMV reverse transcriptase (Amersham Corp., Arlington Heights, IL, USA)를 이용하여 $\mathrm{CDNA}$ 를 합성하였다. DR4 및 DR5에 적절한 primer (Table 1)를 이용한 PCR은 Mastercycler (Eppendorf, Hamburg, Germany)를 사용하여 수행하였으며, PCR 반응 산물을 $1 \%$ agarose을 이용하여 분리한 후, $\mathrm{EtBr}$ 염색을 실시한 후 발 현의 정도를 비교하였다.

\section{단백질 분리 및 Western blot analysis}

특정 유전자의 단백질 발현 변화 분석을 위한 총 단백질은 $25 \mathrm{mM}$ Tris - $\mathrm{Cl}$ (pH 7.5), $250 \mathrm{mM} \mathrm{NaCl}, 5 \mathrm{mM}$ ethylendiaminetetra acetic acid, $1 \%$ nonidet $\mathrm{P}-40,0.1 \mathrm{mM}$ sodium orthovanadate, $2 \mu \mathrm{g} / \mathrm{ml}$ leupeptin 및 $100 \mu \mathrm{g} / \mathrm{ml}$ phenylmethylsulfonyl fluoride가 함유된 lysis buffer를 이용하여 분 리하였다. 분리된 단백질들의 농도를 측정한 후, Western blot analysis를 위해 동량의 단백질들을 sodium dodecyl sulfate (SDS) - polyacrylamide gel electrophoresis를 이용하여 분리 하고 nitrocellulose membrane (Schleicher \& Schuell, Keene, $\mathrm{NH}, \mathrm{USA}$ )으로 전이시켰다. 각각의 membrane을 적정 항체 및 enhanced chemiluminescence (ECL, Amersham Corp., Arlington Heights, IL, USA) 용액을 이용하여 단백질들의 발 현 변화를 조사하였다. 본 실험에 사용된 1차 항체들은 Santa Cruz Biotechnology Inc. (Santa Cruz, CA, USA) 및 Calbiochem (Cambridge, MA, USA)에서 구입하였으며, 2 차 항체들 은 Amersham Corp.에서 구입하였다[5].

\section{세포 내 ROS 생성량의 측정}

세포 내에 축적된 ROS의 양적 변화를 조사하기 위하여 준 비된 세포들을 PBS로 수세 후 fluorescent probe인 2',7'-dichlorodihydrofluorescein diacetate (H2DCFDA, Molecular Probes, Leiden, Netherlands) $10 \mu \mathrm{M}$ 로 20분간 염색 후 DNA flow cytometer (Becton Dickinson)를 이용하여 분석을 하였 다. ROS 생성 억제를 위한 ROS scavenger인 N-acetylcysteine (NAC, Sigma-Aldrich)의 처리는 sanguinarine 및 TRAIL를 처 리하기 1 시간 전처리하였다[13].

\section{통계분석}

모든 실험결과는 평균 \pm 표준편차로 표시하였고 SigmaPlot (Systat Software Inc., San Jose, CA, USA)을 이용하여 Student $t$-test를 이용하여 통계적 유의성을 얻었다.

\section{결 과}

\section{Sanguinarine과 TRAIL의 단독 및 복합처리가 AGS 세 포의 증식에 미치는 영향}

Sanguinarine에 의한 TRAIL 감수성 증대 가능성을 조사하 기 위하여 sanguinarine과 TRAIL 단독 및 복합 처리 24시간 후 MTT assay를 실시하였다. Fig. 1의 결과에서 알 수 있듯이, $0.5 \mu \mathrm{M}$ 의 sanguinarine과 $100 \mathrm{ng} / \mathrm{ml}$ 의 TRAIL 단독 처리군에 서는 유의적인 증식억제 현상이 관찰되지 않았으나, $1.0 \mu \mathrm{M}$ 의 sanguinarine 및 $200 \mathrm{ng} / \mathrm{ml}$ 의 TRAIL 단독 처리군에서는 AGS 세포의 증식이 다소 억제되었다. 그러나 sanguinarine과 TRAIL을 복합 처리할 경우, 단독 처리군에 비하여 처리 농도 의존적으로 현저한 증식억제 현상을 확인 할 수 있었다.

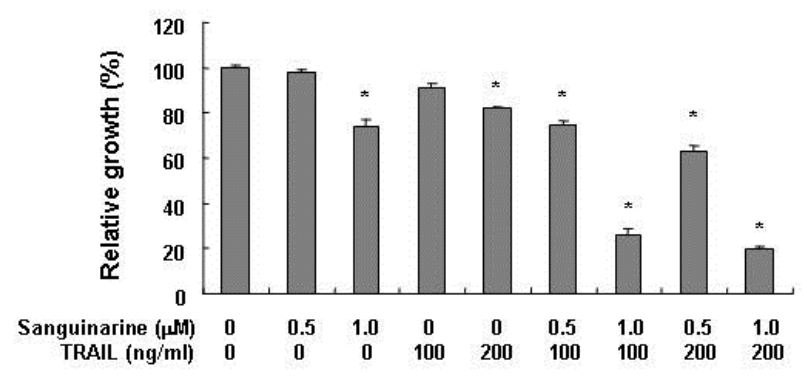

Fig. 1. Synergistic inhibition of cell proliferation by combined treatment of sanguinarine with TRAIL in AGS human gastric adenocarcinoma cells. Cells were seeded at $1 \times 10^{6}$ cells $/ \mathrm{ml}$ and then treated with the indicated concentrations of sanguinarine, TRAIL, or both sanguinarine and TRAIL for $24 \mathrm{hr}$. Cell proliferation assays were done using MTT assay. Each point represents the mean \pm SD of three independent experiments. The significance was determined by Student's t-test $\left({ }^{*} p<0.05\right.$ versus untreated control). 


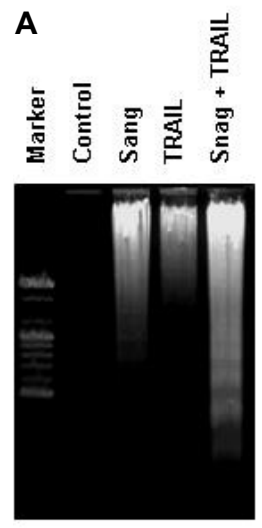

B

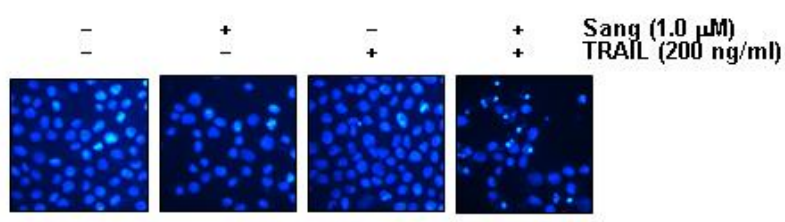

C

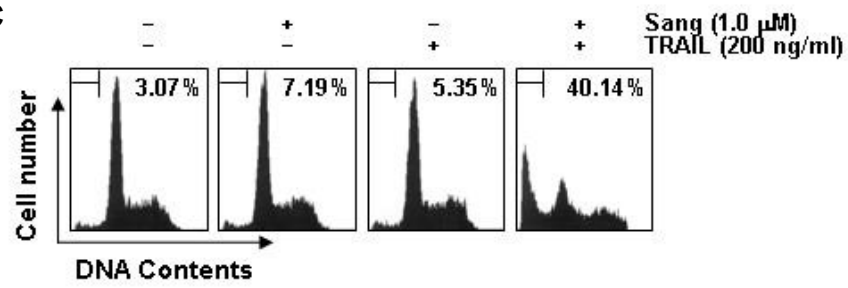

Fig. 2. Synergistic induction of apoptosis by combined treatment with sanguinarine and TRAIL in AGS cells. (A) To analyze the DNA fragmentation, the cells were treated with sanguinarine, TRAIL or both sanguinarine and TRAIL for 24 hr. Fragmented DNA was extracted and analyzed on 1.0\% agarose gel containing EtBr. (B) The apoptotic bodies were examined under a fluorescence microscope (x400) by DAPI staining. (C) The apoptotic sub-G 1 cell population was analyzed by a flow cytometer. Each point represents the mean of two independent experiments.

\section{Sanguinarine과 TRAIL의 복합처리에 의한 AGS 세포의 apoptosis 유발}

이상에서 관찰된 sanguinarine과 TRAIL의 복합처리에 따 른 세포증식 억제 상승효과가 apoptosis 유발과 연관성이 있 는지를 확인하기 위하여 apoptosis가 유발된 세포에서 관찰되 는 몇 가지 apoptosis marker를 조사하였다. 먼저 agarose gel 전기영동에 의한 DNA fragmentation 생성 여부의 결과에서, $1.0 \mu \mathrm{M}$ 의 sanguinarine 및 $200 \mathrm{ng} / \mathrm{ml}$ 의 TRAIL 단독 처리군에 비하여 복합처리군에서 DNA fragmentation 현상이 더욱 증 가되었으며, DAPI staining에 의한 염색질 응축 현상도 복합 처리군에서 현저히 증가되었다(Fig. $2 \mathrm{~A} \mathrm{\&} \mathrm{B).} \mathrm{이들} \mathrm{결과는}$ sanguinarine과 TRAIL의 복합처리에 단독 처리군보다 apoptosis 유발 효과가 높게 나타났음을 보여 주는 것이다. 따라서 apoptosis 유발의 정도를 정량적으로 비교하기 위하여 flow cytometry 분석을 실시한 결과, $1.0 \mu \mathrm{M}$ 의 sanguinarine 및 200 $\mathrm{ng} / \mathrm{ml}$ 의 TRAIL 단독 처리군에서 apoptosis가 유발된 세포의 빈도를 의미하는 sub-G1기 세포의 빈도가 각각 $7.19 \%$ 및 $5.35 \%$ 였음에 비하여, 복합 처리군에서는 $40.14 \%$ 로 나타났다.

\section{Sanguinarine과 TRAIL의 복합처리에 의한 DR5 발현의 증가}

TRAIL에 의한 apoptosis 유발 신호의 개시는 일반적으로 extrinsic pathway를 경유하며, TRAIL은 다양한 DR 중에서 $\mathrm{DR} 4$ 또는 DR5와의 결합을 통하여 apoptosis 신호를 촉진한다 $[15,25]$. 따라서 sanguinarine과 TRAIL의 복합처리에 의한 apoptosis 신호에 미치는 DR의 영향을 조사한 결과, sanguinarine 및 TRAIL 단독 처리군에 비하여 복합처리군에서 DR5 의 발현이 전사 및 번역 수준에서 모두 증가하였다(Fig. 3). 그러나 DR4의 발현은 sanguinarine 및 TRAIL의 단독 처리군 과 복합처리군에서 큰 변화가 관찰되지 않았다.

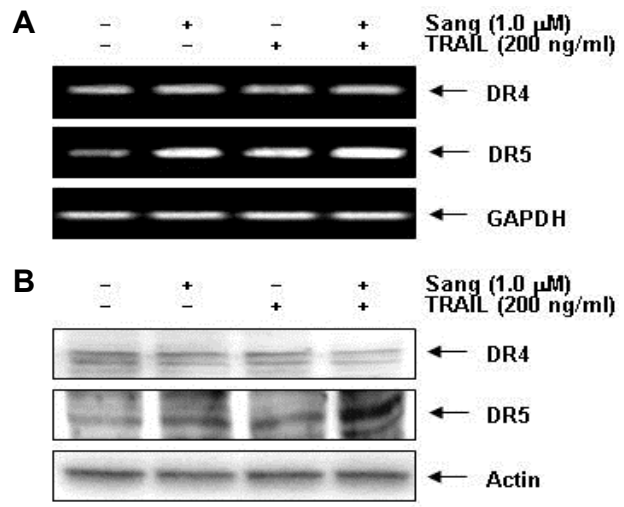

Fig. 3. Induction of DR5 expression by combined treatment with sanguinarine and TRAIL in AGS cells. (A) After treatment with the indicated concentrations of sanguinarine, TRAIL or both sanguinarine and TRAIL for $24 \mathrm{hr}$, total RNAs were isolated and reverse-transcribed. The resulting cDNAs were then subjected to PCR with indicated primers and the reaction products were separated in $1.0 \%$ agarose gel and visualized by EtBr staining. (B) The cell lysates were prepared and equal amounts of total cell lysates were subjected to SDS-polyacrylamide gels, transferred, and probed with the indicated antibodies. Glyceraldehyde-3'-phosphate dehydrogenase (GAPDH) and actin were used as internal controls for the RT-PCR and Western blot assays, respectively.

\section{MAPKs 신호 전달계에 미치는 sanguinarine 및 TRAIL 복합처리의 영향}

최근 apoptosis 유발에 다양한 세포 내 신호계의 활성 변화 가 동반됨이 보고되어 있다. 교아종 세포를 이용한 본 연구실 의 선행 연구에서 sanguinarine에 의한 apoptosis 유발에 ERK 가 관여하고 있었음을 관찰되었기에[11], AGS 세포에서 san- 


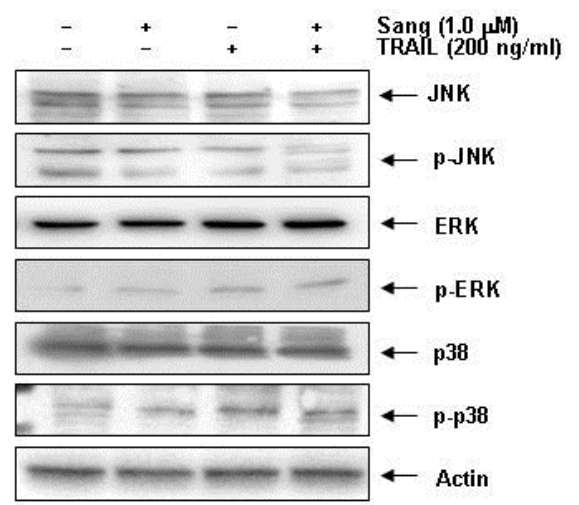

Fig. 4. Effects of sanguinarine and TRAIL on the phosphorylation of MAPKs in AGS cells. After treatment with the indicated concentrations of sanguinarine, TRAIL or sanguinarine and TRAIL for $24 \mathrm{hr}$, the cell lysates were prepared. Equal amounts of total cell lysates were subjected to SDS-polyacrylamide gels, transferred, and then probed with the indicated antibodies. Actin was used as an internal control for the Western blot analysis.

guinarine과 TRAIL 복합처리에 의한 apoptosis에 MAPKs 신 호전달계의 관련성 여부를 조사하였다. Fig. 4 의 결과에서 알 수 있듯이 sanguinarine 및 TRAIL의 단독 처리군과 복합처리 군에서 ERK 뿐만 아니라, JNK 및 p38 MAPK 인산화의 특별 한 증가현상이 뚜렷하게 관찰되지 않았다. 물론 이들 신호계 의 제어를 통한 추가적인 연구가 요구되지만, sanguinarine과 TRAIL 복합처리에 의한 apoptosis 유발에 MAPKs의 관련성 은 상대적으로 낮은 것으로 추정된다.

\section{Sanguinarine 및 TRAIL 복합처리에 의한 apoptosis 유 발에서 ROS의 역할}

다음은 유방암세포를 이용한 선행 연구에서 sanguinarine 에 의한 apoptosis 유발에 ROS의 생성이 필수적으로 동반된 다는 보고 $[7,13,14,16,21,24]$ 를 바탕으로, sanguinarine과 TRAIL 복합처리에 의한 AGS 세포의 apoptosis 유발에서도 $\mathrm{ROS}$ 생성이 관련되어 있는지의 여부를 조사하였다. Fig. 5A에 나타낸 결과에서 알 수 있듯이, sanguinarine과 TRAIL 단독 처리군에 비하여 복합처리군에서 ROS의 생성이 매우 증가되 었지만, ROS scavenger인 NAC 전처리에 의하여 ROS의 생성 이 현저하게 차단되었다. 따라서 NAC 전처리에 의한 AGS 세포의 증식 회복 가능성을 확인한 결과, $\mathrm{NAC}$ 처리에 의한 ROS의 생성 차단으로 sanguinarine과 TRAIL 복합처리에 의 한 증식 억제가 유의적으로 회복되어(Fig. 5B) 두 화합물의 복 합 처리에 의한 증식억제에 ROS 생성이 필수적으로 관여함을 보여주었다.

\section{고 찰}

특정 항암제의 항암활성 측면에서 apoptosis 유도는 암세포
A

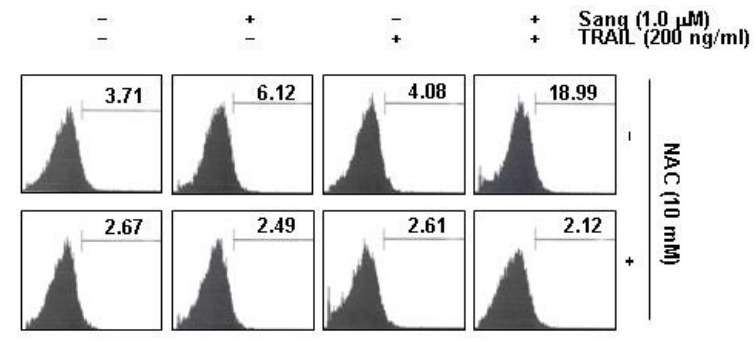

в

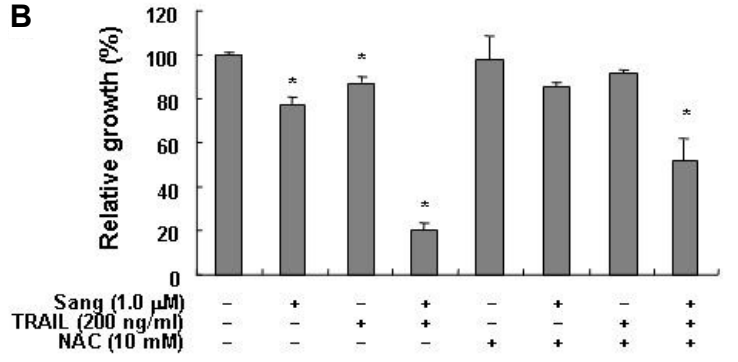

Fig. 5. Effects of ROS scavenger on the generation of ROS and cell viability in sanguinarine and TRAIL-treated AGS cells. AGS cells were treated with sanguinarine and TRAIL for $24 \mathrm{hr}$ after 1-h pre-treatment with NAC (10 $\mathrm{mM})$, a ROS scavenger. (A) The medium was discarded and cells were incubated at $37^{\circ} \mathrm{C}$ in the dark for $20 \mathrm{~min}$ with new culture medium containing $10 \mu \mathrm{M}$ H2DCFDA and then used to evaluate ROS generation by flow cytometry. Each point represents the mean of two independent experiments. (B) Cell proliferation assays were done using MTT assay. Each point represents the mean \pm SD of three independent experiments. The significance was determined by Student's t-test $\left({ }^{*} p<0.05\right.$ versus untreated control).

의 증식을 제어할 수 있는 가장 강력한 수단이라고 할 수 있다. Sanguinarine이 암세포에서 apoptosis를 유도할 수 있다는 연 구는 인체 상피성 세포암(epidermoid carcinoma)에서 처음 보 고[1]된 후 다양한 암세포에서도 apoptosis를 유발할 수 있음 이 밝혀지고 있다 $[3,7,11,12-14,16,20,21,24]$. 이러한 sanguinarine의 항암활성은 세포주기 arrest 비의존적으로 암세포에 서만 발견되는 현상이다.

최근 많은 연구 그룹에 의하여 다양한 암세포에서 TRAIL이 apoptosis를 유도함이 알려진 바 있다[15, 25, 30]. TRAIL에 의한 caspase의 활성을 통한 apoptosis 유도는 암세포의 종류 에 따라 다르지만, caspase-3과 같은 effector caspase의 활성을 직접 촉진하는 미토콘드리아 비의존성인 경로와, caspase-9 활 성을 촉진시키는 미토콘드리아 의존성인 경로로 대별된다[10, $17,22,25]$. TRAIL은 정상세포에서는 apoptosis를 유도하지 못한다는 점에서 암세포 사멸을 위한 항암활성을 가지지만, 본 연구에서 사용된 AGS 위암세포를 포함한 많은 암세포는 이미 TRAIL 저항성이 획득되어 있어 $[5,19,29]$, 암세포 증식 제어를 위한 활용에 한계점을 보이고 있다. 이러한 문제점을 극복하기 위한 방법으로 TRAIL 저항성 암세포에서 TRAIL에 
대한 감수성을 높이기 위한 방법들이 고안되고 있다. 그 중 한 방법이 항암활성을 가지는 물질을 TRAIL과의 복합 처리함 으로서 TRAIL 감수성을 촉진시키는 것으로, 기본적으로 항암 활성이 낮은 조건에서 TRAIL과의 복합 처리로 감수성을 높인 다는 점이다 $[8,9,17,18,21,28]$. 이는 TRAIL 저항성을 가지는 세포 특이적으로 apoptosis를 유발시킨다는 점에서 매우 유용 한 방법으로 TRAIL 감수성을 높이는 후보 물질 발굴은 암 치료를 위한 새로운 전략임이 분명하다. 이러한 관점에서 본 연구에서 나타난 결과와 같이 sanguinarine은 TRAIL 저항성 을 극복할 수 있는 후보 항암물질임이 본 연구실을 포함한 몇몇 연구자들에 의하여 보고된 바 있다[5, 16, 21].

본 연구실의 선행연구에 의하면 sanguinarine은 TRAIL과 의 복합처리에 의하여 AGS 세포에서 apoptosis가 미토콘드리 아 활성 의존적 경로를 통하여 일어났음을 알 수 있었고[7], 유방암세포에서는 ROS의 생성과 anti-apoptotic Bcl-2 및 c-FLIP 발현 저하를 통하여 apoptosis를 유발 시키는 것으로 알려져 있다[21]. 그러나 sanguinarine과 TRAIL의 혼합 처리 에 의한 apoptosis 유발에 대한 정확한 기전은 여전히 많이 밝혀지지 않았기에, 본 연구에서는 AGS 위암세포에서 sanguinarine과 TRAIL 복합처리에 따른 apoptosis 감수성의 증 대에 미치는 추가적인 연구를 실시하였다. 본 연구의 결과를 요약하면, sanguinarine과 TRAIL 혼합 처리에 의한 apoptosis 유발 기전은 ROS의 생성(Fig. 5)과 DR5의 발현 증대(Fig. 3)로 요약할 수 있다. 특히 ROS의 생성은 NAC의 처리에 의하여 완벽하게 차단되었으며(Fig. 5), AGS 위암세포의 유의적인 증 식억제 회복 효과가 관찰되어 sanguinarine의 apoptosis 유발 에서 superoxide radical 역할을 하고 있을 것이라는 선행연구 결과를 뒷받침하여 주는 것이다 $[7,13,14,16,21,24]$. Sanguinarine과 TRAIL의 혼합 처리에 의한 DR5의 발현 증가는, DR5 가 caspase-8의 활성을 통하여 extrinsic pathway를 활성화시 킨다는 점에서 의미가 크다. 또한 sanguinarine은 TRAIL과의 복합처리에 의한 AGS 세포의 apoptosis 유발에는 Bcl-2 family 단백질들의 변화와 Bid의 truncation이 증가되었다는 점[5] 은 TRAIL에 의한 extrinsic pathway의 활성이 촉진되었다는 점을 의미하며, 이는 DR5를 매개로 이루어졌을 가능성을 보여 주는 것이다. 비록 MAPKs 경로의 관련성과 연관되어서는 추 가적인 연구가 이루어져야겠지만, 본 연구의 결과는 TRAIL 저항성을 지니는 암세포의 증식을 제어하기 위한 수단으로 sanguinarine의 활용성에 대한 추가적인 자료를 제시하여 주 는 결과로서 의미가 크다고 생각한다.

\section{감사의 글}

이 논문은 2014학년도 동의대학교 교내연구비에 의해 연구 되었음(2014AA060).

\section{References}

1. Ahmad, N., Gupta, S., Husain, M. M., Heiskanen, K. M. and Mukhtar, H. 2000. Differential antiproliferative and apoptotic response of sanguinarine for cancer cells versus normal cells. Clin Cancer Res 6, 1524-1528.

2. Bambagiotti-Alberti, M., Pinzauti, S., Moneti, G., Gratteri, P., Coran, S. A. and Vincieri, F. F. 1991. Characterization of Sanguinaria canadensis L. fluid extract by FAB mass spectrometry. J Pharm Biomed Anal 9, 1083-1087.

3. Becci, P. J., Schwartz, H., Barnes, H. H. and Southard, G. L. 1987. Short-term toxicity studies of sanguinarine and of two alkaloid extracts of Sanguinaria canadensis L. J Toxicol Environ Health 20, 199-208.

4. Bellail, A. C., Qi, L., Mulligan, P., Chhabra, V. and Hao, C. 2009. TRAIL agonists on clinical trials for cancer therapy: the promises and the challenges. Rev Recent Clin Trials 4, 34-41.

5. Choi, W. Y., Jin, C. Y., Han, M. H., Kim, G. Y., Kim, N. D., Lee, W. H., Kim, S. K. and Choi, Y. H. 2009. Sanguinarine sensitizes human gastric adenocarcinoma AGS cells to TRAIL-mediated apoptosis via down-regulation of AKT and activation of caspase-3. Anticancer Res 29, 4457-4465.

6. Choi, Y. H., Choi, W. Y., Hong, S. H., Kim, S. O., Kim, G. Y., Lee, W. H. and Yoo, Y. H. 2009. Anti-invasive activity of sanguinarine through modulation of tight junctions and matrix metalloproteinase activities in MDA-MB-231 human breast carcinoma cells. Chem Biol Interact 179, 185-191.

7. Choi, W. Y., Kim, G. Y., Lee, W. H. and Choi, Y. H. 2008. Sanguinarine, a benzophenanthridine alkaloid, induces apoptosis in MDA-MB-231 human breast carcinoma cells through a reactive oxygen species-mediated mitochondrial pathway. Chemotherapy 54, 279-287.

8. Cretney, E., Takeda, K. and Smyth, M. J. 2007. Cancer: novel therapeutic strategies that exploit the TNF-related apoptosis-inducing ligand (TRAIL)/TRAIL receptor pathway. Int J Biochem Cell Biol 39, 280-286.

9. Fulda, S. 2008. Modulation of TRAIL-induced apoptosis by HDAC inhibitors. Curr Cancer Drug Targets 8, 132-140.

10. Galluzzi, L., Larochette, N., Zamzami, N. and Kroemer, G. 2006. Mitochondria as therapeutic targets for cancer chemotherapy. Oncogene 25, 4812-4830.

11. Han, M. H., Kim, S. O., Kim, G. Y., Kwon, T. K., Choi, B. T., Lee, W. H. and Choi, Y. H. 2007. Induction of apoptosis by sanguinarine in $\mathrm{C} 6$ rat glioblastoma cells is associated with the modulation of the Bcl-2 family and activation of caspases through downregulation of extracellular signal-regulated kinase and Akt. Anticancer Drugs 18, 913-921.

12. Han, M. H., Yoo, Y. H. and Choi, Y. H. 2008. Sanguinarine-induced apoptosis in human leukemia U937 cells via Bcl-2 downregulation and caspase-3 activation. Chemotherapy 54, 157-165.

13. Han, M. H., Kim, G. Y., Yoo, Y. H. and Choi, Y. H. 2013. Sanguinarine induces apoptosis in human colorectal cancer HCT-116 cells through ROS-mediated Egr-1 activation and mitochondrial dysfunction. Toxicol Lett 220, 157-166. 
14. Han, M. H., Park, C., Jin, C. Y., Kim, G. Y., Chang, Y. C., Moon, S. K., Kim, W. J. and Choi, Y. H. 2013. Apoptosis induction of human bladder cancer cells by sanguinarine through reactive oxygen species-mediated up-regulation of early growth response gene-1. PLOS One 8, e63425.

15. Henson, E. S., Johnston, J. B. and Gibson, S. B. 2008. The role of TRAIL death receptors in the treatment of hematological malignancies. Leuk Lymphoma 49, 27-35.

16. Hussain, A. R., Al-Jomah, N. A., Siraj, A. K., Manogaran, P., Al-Hussein, K., Abubaker, J., Platanias, L. C., Al-Kuraya, K. S. and Uddin, S. 2007. Sanguinarine-dependent induction of apoptosis in primary effusion lymphoma cells. Cancer Res 67, 3888-3897.

17. Jeong, S. Y. and Seol, D. W. 2008. The role of mitochondria in apoptosis. $B M B$ Rep 41, 11-22.

18. Jin, C. Y., Moon, D. O., Lee, J. D., Heo, M. S., Choi, Y. H., Lee, C. M., Park, Y. M. and Kim, G. Y. 2007. Sulforaphane sensitizes tumor necrosis factor-related apoptosis-inducing ligand-mediated apoptosis through downregulation of ERK and AKT in lung adenocarcinoma A549 cells. Carcinogenesis 28, 1058-1066.

19. Jin, C. Y., Park, C., Cheong, J., Choi, B. T., Lee, T. H., Lee, J. D., Lee, W. H., Kim, G. Y., Ryu, C. H. and Choi, Y. H. 2007. Genistein sensitizes TRAIL-resistant human gastric adenocarcinoma AGS cells through activation of caspase-3. Cancer Lett 257, 56-64.

20. Kemény-Beke, A., Aradi, J., Damjanovich, J., Beck, Z., Facskó, A., Berta, A. and Bodnár, A. 2006. Apoptotic response of uveal melanoma cells upon treatment with chelidonine, sanguinarine and chelerythrine. Cancer Lett 237, 67-75.

21. Kim, S., Lee, T. J., Leem, J., Choi, K. S., Park, J. W. and Kwon, T. K. 2008. Sanguinarine-induced apoptosis: Generation of ROS, down-regulation of BCL-2, c-FLIP, and synergy with TRAIL. J Cell Biochem 104, 895-907.

22. Kroemer, G., Galluzzi, L. and Brenner, C. 2007. Mitochondrial membrane permeabilization in cell death. Physiol Rev 87, 99-163.

23. Lenfeld, J., Kroutil, M., Marsalek, E., Slavik, J., Preininger, V. and Simanek, V. 1981. Antiinflammatory activity of quaternary benzophenanthridine alkaloids from Chelidonium majus. Planta Med 43, 161-165.

24. Matkar, S. S., Wrischnik, L. A. and Hellmann-Blumberg, U. 2008. Sanguinarine causes DNA damage and p53-independent cell death in human colon cancer cell lines. Chem Biol Interact 172, 63-71.

25. Mérino, D., Lalaoui, N., Morizot, A., Solary, E. and Micheau, O. 2007. TRAIL in cancer therapy: present and future challenges. Expert Opin Ther Targets 11, 1299-1314.

26. Mitscher, L. A., Park, Y. H., Clark, D., Clark III, G. W., Hammesfahr, P. D., Wu, W. N. and Beal, J. L. 1978. Antimicrobial agents from higher plants. An investigation of Hunnemannia fumariaefolia pseudoalcoholates of sanguinarine and chelerythrine. Lloydia 41, 145-150.

27. Seifen, E., Adams, R. J. and Riemer, R. K. 1979. Sanguinarine: a positive inotropic alkaloid which inhibits cardiac $\mathrm{Na}^{+}$, $\mathrm{K}^{+}$-ATPase. Eur J Pharmacol 60, 373-377.

28. Wu, X. X., Ogawa, O. and Kakehi, Y. 2004. TRAIL and chemotherapeutic drugs in cancer therapy. Vitam Horm 67, 365383.

29. Yang, L. Q., Fang, D. C., Wang, R. Q. and Yang, S. M. 2004. Effect of NF-kB, survivin, BCL-2 and caspase-3 on apoptosis of gastric cancer cells induced by tumor necrosis factor-related apoptosis inducing ligand. World J Gastroenterol 10, 22-25.

30. Zhang, L. and Fang, B. 2005. Mechanisms of resistance to TRAIL-induced apoptosis in cancer. Cancer Gene Ther 12, 228-237.

31. Zhou, P., Cheng, S. W., Yang, R., Wang, B. and Liu, J. 2012. Combination chemoprevention: future direction of colorectal cancer prevention. Eur J Cancer Prev 21, 231-240. 


\section{초록 : AGS 인체 위암세포에서 DR5의 발현 및 ROS 생성의 증가를 통한 sanguinarine과 TRAIL 혼합처리의 apoptosis 유도 활성 촉진}

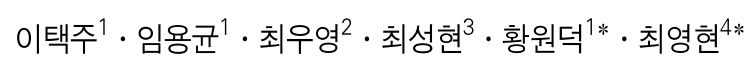

( ${ }^{1}$ 동의대학교 한의과대학 내과학교실, ${ }^{2}$ 부산대학교 한의학전문대학원 경락구조의학부, ${ }^{3}$ 한국승강기대학교 승강기시스템관리과, ${ }^{4}$ 동의대학교 한의과대학 생화학교실, 항노화연구소 및 블루바이오소재개발센터)

혈근초(Sanguinaria canadensis) 뿌리에서 유래된 benzophenanthridine alkaloid의 일종인 sanguinarine은 항균, 항산화 및 항암작용 등 다양한 생리활성을 지니고 있는 것으로 알려져 있다. 비록 TRAIL이 암세포에서는 apoptosis를 유도하지만 정상세포에서는 세포독성을 나타내지 않는다는 큰 장점으로 제 2 임상 단계에서 유의적인 성과 를 이루었지만, TRAIL 저항성을 극복해야 하는 큰 어려움이 남아있다. 본 연구실에서는TRAIL이 세포독성을 나타 내지 않는 범위의 sanguinarine과 혼합처리에 의하여 TRAIL 저항성 AGS 위암세포에서 apoptosis를 유발하였음 을 보고한 바 있으며, 본 연구에서는 sanguinarine의 TRAIL 저항성 관련 극복에 대한 추가적인 기전 연구를 실시 하였다. 본 연구의 결과에 의하면, sanguinarine과 TRAIL의 혼합처리는 각각의 단독 처리에 비하여 AGS 세포의 증식억제 및 apoptosis 유도의 상승 효과가 있었으며, 이를 MTT assay, agarode gel 전기영동, 염색질 응축 현상 및 flow cytometry 분석을 통하여 확인하였다. 또한 sanguinarine과 TRAIL의 혼합처리는 DR5의 발현을 증가시켰 으며, ROS의 생성을 촉진시켰다. 그러나 동일 조건에서 MAPKs 신호 전달계에는 큰 영향을 주지 않았다. 아울러 $\mathrm{ROS}$ 생성을 인위적으로 차단하였을 경우, sanguinarine과 TRAIL의 혼합처리에 의한 생존도 저하가 유의적으로 회복되었다. 이러한 결과는 sanguinarine과 TRAIL이 DR5의 발현 증가와 ROS의 생성을 촉진시킴으로서 apoptosis 신호를 활성화하였음을 의미하는 결과로서 TRAIL 저항성 극복을 위한 sanguinarine 활용의 유용성을 보여주 는 것이다. 